\title{
Construction of Evaluation Index System of University Students' Innovation Ability Based on Social Network Analysis
}

\author{
Fei Bian \\ Institutional Research Center of Shenzhen Polytechnic, \\ Shenzhen, 518055, China \\ 371247627@qq.com
}

\begin{abstract}
University students can drive the country's technological progress with their innovative ability. However, in reality, most researches have not gone in-depth into the study of the components of university students' innovation ability or the evaluation index system. This paper, on the basis of the quantitative analysis on literature, works out initially the innovation ability evaluation index system of university students. Then, data collected from the questionnaire and social network analysis tool are adopted to select appropriate indexes. With the introversion centrality the screening criterion, it builds the innovation ability evaluation index system of university students. The system consists of six primary indicators and 36 secondary indicators, which provides reference and guidance for evaluating university students' innovation ability.
\end{abstract}

Keywords-university students; innovation ability; evaluation index system; social network analysis

\section{INTRODUCTION}

University students are the main force for innovation, which drives the country's technological advance. It is the priority of higher education to cultivate students' innovative spirit and capability. A scientific innovation ability evaluation system of university students is not only helpful for colleges and universities to open innovative courses and arrange corresponding innovative practices, effectively improve the innovation education in colleges and universities, but also helpful for university students to get an objective understanding of their own innovation ability, so as to make efforts as is needed. Through literature review, this paper summarizes carries out statistical analysis of the factors influencing students' innovative ability, establishes an evaluation index system of university students' innovation ability, and then uses questionnaire survey data and social network analysis tools to build an evaluation index system of university students' innovation ability based on the principle of internal centrality, providing reference and guidance for the evaluation of university students’ innovation ability.

Fund Project: key project of Shenzhen Branch of National Institute of Vocational Education in 2017: Research on Ways to Promote Innovative Awareness of Students of Higher Vocational College: Structural Equation Analysis Based on Innovative Awareness, Behavior and Performance (No. 7017-22J400049991); Shenzhen Polytechnic "Innovative and Entrepreneurial Education Special Project” in 2018: Technology Research on the Training System and Assessment Criteria of Innovative Thinking and Entrepreneurship Ability of Skilled Talents (No. 701822J43C17)

\section{LITERATURE REVIEW}

\section{A. The innovative ability of university students}

Amabile [1] believes that innovation ability consists of innovation motivation, innovation knowledge and innovation skills. Qian Zhaochu [2] considers that university students' innovative ability includes four aspects, that is, thinking innovation ability, lifelong learning ability, self-management ability and innovative practical ability. Zhang Yuanyuan [3] found that the innovation ability of university students depends on five aspects, namely, innovation consciousness, innovation spirit, innovative thinking, knowledge structure and practical ability. Lu Jingdan et al. [4] built a measurement model of university students' innovation ability based on SEM, and believed that the innovation ability contains innovation consciousness and innovation skill. Innovation consciousness consists of observation, imagination and inquiry ability while innovative skills involve information processing and hands-on operation skills.

\section{B. Factors influencing university students' innovation ability}

On the basis of literature review, Cui Hongqiao et al. [5] made a qualitative and quantitative study of the factors affecting the cultivation of university students' innovative ability, and concluded that the factors such as innovative incentive mechanism, innovative practical training and social atmosphere will have an impact on the cultivation of the innovative ability. Based on the influencing factors model of university students' innovative thinking ability, Li Cunjin et al. [6], through quantitative analysis, concluded that university students' innovative thinking ability is relatively low, which is influenced by their own dimension, education system dimension and family education dimension. Cui Huibin [7] made a quantitative analysis of the relationship between information literacy and university students' innovation and entrepreneurship ability. Combining with structural equation model analysis, he concluded that information literacy has a significant impact on university students' innovation ability, and put forward corresponding measures and suggestions.

\section{Evaluation of university students' innovative ability}

Fudan et al. [8] qualitatively analyzed the innovative ability of university students by questionnaire survey and experts grading method, and evaluated the innovative ability of university students by extension comprehensive evaluation 
method. The results showed that the evaluation of the innovative ability of university students by extension comprehensive evaluation is more objective and scientific. Li Yanpo et al. [9] summarized the evaluation indexes of innovation ability of university students at home and abroad, and combined with the characteristics of higher vocational colleges in China, put forward the related evaluation index system in Chinese higher vocational colleges, and used the fuzzy comprehensive evaluation to assess the innovation ability of university students. Gu Jun [10] used the questionnaire survey and expert scoring method to construct the evaluation index of university students' innovative ability, and preliminary applied the index system combined with fuzzy comprehensive evaluation.

Through the literature, it is found that the influencing factors involved in the evaluation index system of university students' innovation ability are not comprehensive enough. Therefore, based on the literature analysis, this paper intends to use the social network analysis method to construct a systematic and scientific evaluation index system of university students' innovation ability.

\section{CONSTRUCTION OF EVAluATION INDEX SYSTEM OF UNIVERSITY STUDENTS’ INNOVATION ABILITY}

Based on the analysis and extraction of relevant research literature, this paper summarizes the factors affecting university students' innovative ability and builds the evaluation index system of university students' innovative ability for the first time. Then, the relationship matrix between samples and indicators is obtained by using questionnaire data, and the selection of indicators is completed by using social network analysis tools.

\section{A. Initial construction of the evaluation index system of university students' innovation ability}

303 journals in this paper are all collected from CNKI by typing in keywords like "University Students' Innovative Ability”, "University Students' Innovative Ability Assessment”, "Innovative Evaluation Index", "Influencing Factors of Innovative Ability" and setting the retrieval period from July 2009 to July 2019. Based on the contents of the indicators built by domestic and foreign scholars, this paper interprets, analyses, codes, collates and synthesizes the factors affecting university students' innovative ability, deletes indicators whose frequency are less than five times, and summarizes the secondary indicators as shown in table 1 .

TABLE I. EVALUATION INDEX SYSTEM OF UNIVERSITY STUDENTS’ INNOVATION ABILITY (INITIAL)

\begin{tabular}{|c|c|c|c|}
\hline Indexes & Connotation of index & Indexes & Connotation of index \\
\hline Innovative consciousness & Motivation to create new things or ideas & Awareness of adventure & Interest in exploring new things \\
\hline $\begin{array}{l}\text { Entrepreneurship competition } \\
\text { award } \\
\end{array}$ & Innovative practical achievements & Publish of academic papers & Innovative achievements \\
\hline Intuitive thinking & $\begin{array}{l}\text { Thinking pattern of understanding the essence } \\
\text { of things }\end{array}$ & Critical thinking & Quality of questioning authority \\
\hline Basic knowledge & Foundation of innovation & Relevant knowledge & Information or skills related to innovation \\
\hline Knowledge integration ability & Knowledge transfer and connectivity & Knowledge renewal ability & Updating and iteration of knowledge system \\
\hline Social practice & Holiday or off-campus internship & $\begin{array}{l}\text { Research on scientific } \\
\text { projects }\end{array}$ & Innovative achievements \\
\hline Exploratory consciousness & Interest in the unknown & $\begin{array}{l}\text { Strive hard and make } \\
\text { progress }\end{array}$ & Positive performance \\
\hline Quality of graduation design & Ability to apply professional knowledge & Application for patent & Innovative achievements \\
\hline Divergent thinking & $\begin{array}{l}\text { Thoughts that do not conform to convention } \\
\text { and seek innovation }\end{array}$ & Overcome difficulties & Ability to solve difficult problems \\
\hline Professional knowledge & Stable and systematic knowledge & Digital model competition & Innovative achievements \\
\hline $\begin{array}{l}\text { Knowledge acquisition } \\
\text { ability }\end{array}$ & Ability to acquire and master new knowledge & Information retrieval ability & Ability to collect and integrate information \\
\hline Experimental practical ability & Hands-on and problem-solving skills & Internship experience & Learning experience from practice \\
\hline Questioning spirit & Doubt about existing things & $\begin{array}{c}\text { Analytical and } \\
\text { comprehensive ability }\end{array}$ & Connection and distinction between things \\
\hline Quality of course design & Ability to apply professional knowledge & Student work & Team work experience \\
\hline Logical thinking & Law of understanding and reflecting things & $\begin{array}{l}\text { Ability to discover and solve } \\
\text { problem }\end{array}$ & Ability to discover and solve problems \\
\hline Innovative knowledge & Innovative technologies, methods and practices & Academic conference & $\begin{array}{l}\text { Acquisition of professional knowledge and } \\
\text { information }\end{array}$ \\
\hline $\begin{array}{l}\text { Knowledge acceptance } \\
\text { ability }\end{array}$ & $\begin{array}{l}\text { Acquisition, absorption and utilization of } \\
\text { knowledge }\end{array}$ & Professional interest & A need for something \\
\hline Market research capability & $\begin{array}{c}\text { Ability to collect and analyze market } \\
\text { conditions }\end{array}$ & Moral character & $\begin{array}{l}\text { Ideological criteria for measuring the } \\
\text { legitimacy of behavior }\end{array}$ \\
\hline Self-confidence & Degree of trust in one's ability & Firm will & Degree of firmness to achieve a certain goal \\
\hline Skill training & Ways to acquire innovative skills & Knowledge transfer ability & $\begin{array}{l}\text { Use of existing knowledge to solve new } \\
\text { problems }\end{array}$ \\
\hline
\end{tabular}


B. Selection of evaluation index of university students' innovation ability

\section{1) Social network analysis}

A social network represents a form of social organization in which points and points are interconnected in some way. The points usually refer to individuals or organizations, and their connection means different social relationships. Individuals or organizations form a relatively stable relationship system based on a certain connection. The social network analysis was originally proposed by the famous British anthropologist Professor Brown in the 1930s to study the behavior of members of the bounded group. Chinese scholar Wang Yifei et al. [11] used the social network analysis method to construct the measurement index system of enterprise technology innovation capability, which enriched the application scope of social network analysis methods.

The primary condition of borrowing social network analysis is to clarify the internal associations of each unit, which is the premise of social network analysis. The correlation of social network analysis is oriented, that is, it can not only reflect whether any two units are related, but also mirror the direction of association between them. By establishing the relationship among all units in the network, the association form between them is built to reflect its relationship network. After building the network, it is necessary to calculate the importance of each node (that is, each cell) in the network, namely, the introversion centrality of the network. Introversion centrality of network is mainly used to reflect the status and rights of nodes, which can be classified into three subcategories: degree centrality, intermediate centrality and proximity centrality. Among them, degree centrality is mainly used to measure the importance of network nodes. The higher its value is, the bigger its impact is.

\section{2) Selection of index}

This paper selected the senior students from Sun Yat-sen University, South China Normal University, Southern University of Science and Technology, and Shenzhen University as the subjects of the survey. 400 questionnaires were distributed and 380 valid questionnaires were collected, with an effective recovery rate of $95 \%$.

The samples and primary and secondary index are regarded as network nodes. The relationship between samples and indicators is defined as the connection line or edge of the network. The importance of indicators is quantified by social network analysis, and the results are visually displayed. Introversion centrality is used as the selection criterion of the index, and the degree centrality of each index is calculated to measure its importance, so as to complete the selection of the evaluation index system of university students' innovation ability.

Based on the results of the questionnaire, the matrix relationship of "sample: secondary index" is constructed respectively, as shown in table 2 . Among them, every row in the matrix is composed of sample survey data, and the secondary index is the initial construction of the index system. The $0-1$ value reflects whether the sample approves of this index as a factor affecting university students' innovative ability. One represents full approval, and zero shows total disapproval. The basic attribute values of the secondary indicators are calculated by using the social network analysis software Ucinet.

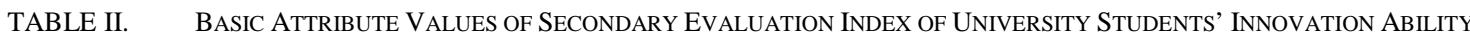

\begin{tabular}{|c|c|c|c|c|c|c|c|}
\hline Secondary index & Degree & NrmDegree & Share & Secondary index & Degree & NrmDegree & Share \\
\hline Innovative consciousness & 61.000 & 67.155 & 0.056 & Knowledge transfer ability & 20.00 & 34.459 & 0.019 \\
\hline Exploratory consciousness & 57.000 & 63.879 & 0.055 & Knowledge acceptance ability & 20.00 & 34.459 & 0.019 \\
\hline Questioning spirit & 55.000 & 61.547 & 0.052 & Knowledge renewal ability & 20.000 & 34.459 & 0.019 \\
\hline Strive hard and make progress & 49.000 & 58.435 & 0.047 & Experimental practical ability & 19.000 & 32.855 & 0.017 \\
\hline Overcome difficulties & 47.000 & 57.921 & 0.045 & Market research ability & 18.000 & 31.522 & 0.016 \\
\hline Entrepreneurship competition award & 43.000 & 56.678 & 0.042 & Research on scientific research projects & 18.000 & 31.522 & 0.016 \\
\hline Quality of graduation design & 41.000 & 56.452 & 0.039 & Internship experience & 16.000 & 26.588 & 0.014 \\
\hline Quality of course design & 39.000 & 54.375 & 0.037 & Student work & 14.000 & 25.456 & 0.013 \\
\hline Publish of academic papers & 37.000 & 53.587 & 0.036 & Academic conference & 13.000 & 24.543 & 0.012 \\
\hline Application for patent & 36.000 & 53.114 & 0.035 & Professional interest group & 13.000 & 23.455 & 0.012 \\
\hline Digital model competition & 35.000 & 52.456 & 0.031 & Skill training & 12.000 & 21.571 & 0.017 \\
\hline Intuitive thinking & 33.000 & 50.458 & 0.031 & Information retrieval ability & 11.000 & 20.241 & 0.009 \\
\hline Divergent thinking & 32.000 & 49.872 & 0.028 & Analytical and comprehensive ability & 10.000 & 18.253 & 1.000 \\
\hline Logical thinking & 31.000 & 48.259 & 0.027 & Mean & 17.892 & 24.571 & 0.017 \\
\hline Critical thinking & 29.000 & 47.256 & 0.026 & Std Dev & 17.325 & 11.241 & 0.009 \\
\hline Professional knowledge & 26.000 & 41.346 & 0.024 & Variance & 73.168 & 152.129 & 0.000 \\
\hline Innovative knowledge & 26.000 & 41.346 & 0.024 & SSQ & 2649.000 & 49761.276 & 0.031 \\
\hline Relevant knowledge & 23.000 & 39.355 & 0.023 & MCSSQ & 4831.598 & 12899.535 & 0.006 \\
\hline Knowledge integration ability & 23.000 & 39.355 & 0.023 & Euc Norm & 151.339 & 264.834 & 0.156 \\
\hline \multirow[t]{2}{*}{ Knowledge acquisition ability } & 21.000 & 37.346 & 0.021 & Minimum & 10.000 & 18.253 & 1.000 \\
\hline & & & & Maximum & 61.000 & 67.155 & 0.056 \\
\hline \multicolumn{8}{|c|}{$\begin{array}{c}\text { Network Centralization }=51.62 \% \\
\text { Heterogeneity }=1.93 \% \text {. Normalized }=0.49 \%\end{array}$} \\
\hline
\end{tabular}

According to table 2, the centrality of index network reaches $51.62 \%$. From innovation awareness to research projects, its introversion centrality index ranges from 61 to 18 , exceeding the average of 17.892; the lowest centrality of 
standardization is 31.522, which has high acceptability. However, the introversion centrality of internship experience, student work and other indicators are lower than the average value of the overall network of 17.892 , so the 7 indicators are discarded, and the remaining 36 secondary indicators are used as secondary indicators for the evaluation of university students' innovation ability.

According to the two-level index system, this paper classifies the similar indicators of semantic expression into one group through induction and analysis, and extracts the first- level indicators of this paper, which are: (1) personal traits, that is, needed characteristics of individual innovation of university students; (2) innovation transfer ability, namely, individual innovation achievements; (3) thinking ability, that is, innovative thinking of university students; (4) ability of knowledge reserve, namely, knowledge and skills that university students use to innovate; (5) learning ability, that is, renewal and iteration of university students' knowledge; (6) practical ability, namely, practical experience of university students' innovation. See table 3 for details.

TABLE III. EVALUATION INDEX SySTEM OF UNIVERSITY STUDENTS’ INNOVATION ABILITY

\begin{tabular}{|c|c|c|c|}
\hline Primary indicator & Secondary indicator & Primary indicator & Secondary indicator \\
\hline \multirow{6}{*}{ Personal qualities } & Innovative consciousness & \multirow{6}{*}{ Innovation transfer ability } & $\begin{array}{c}\text { Entrepreneurship competition } \\
\text { award }\end{array}$ \\
\hline & Exploratory consciousness & & Quality of graduation design \\
\hline & Questioning spirit & & Quality of course design \\
\hline & Awareness of adventure & & Publish of academic papers \\
\hline & $\begin{array}{l}\text { Strive hard and make } \\
\text { progress }\end{array}$ & & Application for patent \\
\hline & Overcome difficulties & & Digital model competition \\
\hline \multirow{4}{*}{ Knowledge reserve capacity } & Basic knowledge & \multirow{4}{*}{ Learning ability } & Knowledge integration ability \\
\hline & Professional knowledge & & Knowledge transfer ability \\
\hline & Innovative knowledge & & Knowledge acceptance ability \\
\hline & Relevant knowledge & & Knowledge renewal ability \\
\hline \multirow{4}{*}{ Thinking ability } & Intuitive thinking & \multirow{4}{*}{ Practical ability } & Social practice \\
\hline & Divergent thinking & & Experimental practical ability \\
\hline & Logical thinking & & Market research ability \\
\hline & Critical thinking & & $\begin{array}{l}\text { Research on scientific } \\
\text { research projects }\end{array}$ \\
\hline
\end{tabular}

\section{CONCLUSIONS}

This paper makes a quantitative analysis of domestic research literature on university students' innovative ability, and constructs an evaluation index system of it based on questionnaire survey and social network analysis. The study draws the following conclusions:

(1) By sorting out and summarizing the relevant literature on university students' innovative ability, the influencing factors of which are preliminarily extracted. Combined with questionnaire survey data and social network analysis tools, the introversion centrality is used as the screening criterion, and the secondary indicators of university students' innovation ability evaluation are determined. Through further refining, the second-level indicators, the first-level indicators for evaluating the ability are summarized. The index system consists of six first-level indicators and 36 second-level indicators.

(2) On the basis of literature analysis, it is partly systematic and scientific of the evaluation index system of university students' innovation ability built by questionnaire survey and social network analysis, which can reflect the research viewpoints of most domestic scholars and truly mirror the main factors affecting the innovation ability. Furthermore, it is relatively convincing to effectively evaluate university students' innovative ability.

\section{REFERENCES}

[1] Amabile T M. The Social Psychology of Creativity [M]. Springer New York, 1983
[2] Qian Zhaochu. The Value Connotation and Training of University Students’ Innovation Ability [J]. China Adult Education,2016, (01):8385.

[3] Zhang Yuanyuan. A Survey on the Innovation Ability of English Majors - A Case Study of Wuhan Universities [J]. Education Research Monthly, 2012, (06):41-43.

[4] Lu Jingdan, Chen Peiling. SEM-Based Innovation Ability Measurement Model for University Students [J]. Statistics \& Decision,2011, (03):7173.

[5] Cui Hongqiao, Liu Wenchao, Wang Hong. An Empirical Study on the Factors Influencing the Cultivation of Innovation Ability of University Students Major in Business Administration [J]. Journal of Southwest China Normal University (Natural Science Edition),2013, (02):160-164.

[6] Li Cunjin, Yan Yongjing, Yang Qing. Empirical Analysis of the Factors Influencing the Formation of University Students' Innovative Thinking Ability [J]. Technical Economy,2013, (03):29-35.

[7] Cui Huibin. The Influence of University Students' Information Literacy on Their Innovation and Entrepreneurship Ability [J]. Chinese University Science \& Technology, 2017, (03):86-89.

[8] Fu Dan, He Zhifang, Ke Yu. Application of Extension Comprehensive Evaluation Method in Assessment of University Students' Innovation Ability [J]. Education Research Monthly, 2015, (08):47-52.

[9] Li Yanpo, Fan Hairong, He Shangqin, Gao Mingjing, Wang $\mathrm{Na}$ Research on Evaluation Index System and Evaluation Method of College Students' Innovation Ability in Higher Vocational Colleges [J]. China Adult Education, 2010, (16):29-31.

[10] Gu Zhun. The Establishment and Application of the Evaluation Indicator System for Undergraduate Students' Innovation Capability [J]. Journal of Yancheng Institute of Technology (Social Science Edition), 2015, (01):91-94.

[11] Wang Yifei, Xiao Jiuling, Wang Jiankang. Measurement of Enterprise Technological Innovation Capability--from the Perspective of Social Network Analysis [J]. Science \& Technology Progress and Policy, 2011, (15):77-81. 